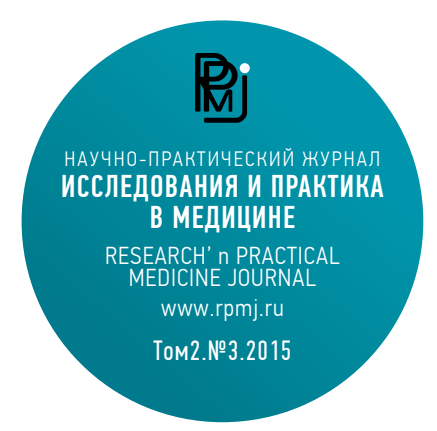

Ключевые слова:

бактериофаги, антисептики, хлоргексидин, мирамистин, литическая активность, цитотоксичность, Staphylococcus aureus, Streptococcus pyogenes

Keywords:

bacteriophages, antiseptics, chlorhexidine, miramistin, Iytic activity, cytotoxicity, Staphylococcus aureus, Streptococcus pyogenes

DOI: 10.17709/2409-2231-2015-2-3-35-42

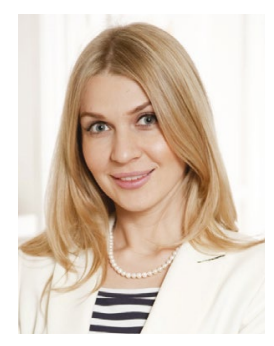

Для корреспонденции: Пашкова Галина Сергеевна, К.М.Н., врач-стоматолог-хирург КДК ГБОУ ВПО МГМСУ им. А.И. Евдокимова МЗ РФ Адрес: 127006, г. Москва, ул. Долгоруковская, д.4. E-mail: pashkova@apluspha.ru Статья поступила 31.07.2015, принята к печати 30.08.2015

For correspondence:

Pashkova Galina Sergeevna,

PhD, dentist surgeon, A.I. Evdokimov

KDK GBEO HPE MSMSU MH RF

Address: 127006, Moscow, ul. Dolgorukovskaya, 4

E-mail: pashkova@apluspha.ru

The article was received 31.07.2015

accepted for publication 30.08 .2015

\section{ИЗУЧЕНИЕ ЭФФЕКТИВНОСТИ И БЕЗОПАСНОСТИ ПРИМЕНЕНИЯ АНТИМИКРОБНЫХ СРЕДСТВ}

\author{
Багаева В.В. ${ }^{1}$, Попова В.М. ${ }^{2}$, Пашкова Г.С. ${ }^{3}$, Исаджанян К.Е. ${ }^{4}$,
} Никитин В.В. ${ }^{5}$ Ж Жиленков Е.Л. ${ }^{2}$

1 Покровский банк стволовых клеток (Санкт-Петербург, Российская Федерация)

199106, г.Санкт-Петербург, Большой пр. В.О., д.85

${ }^{2}$ НПЦ «МикроМир» (Любучаны, Российская Федерация)

142380, Московская обл., Чеховский р-н, пос. Любучаны, Институт Инженерной Иммунологии

${ }^{3}$ КДК ГБОУ ВПО МГМСУ им. А.И. Евдокимова МЗ РФ (Москва, Российская Федерация)

127006, г. Москва, ул. Долгоруковская, д.4

${ }^{4}$ ЦНИИС и ЧЛХ (Москва, Российская Федерация)

119021 , г. Москва, ул. Тимура Фрунзе, д.16,

5 «Клиника Боско» (Москва, Российская Федерация)

107031, г. Москва, ул. Неглинная, д.13

\section{Резюме:}

Эффективное лечение пациентов с инфекционно-воспалительными заболеваниями кожи и слизистых оболочек часто включает применение антимикробных средств.

Целью исследования явилось изучение in vitro эффективности и цитотоксичности отечественных средств для местного применения: гелей с бактериофагами («Отофаг», «Фагогин», «Фагодерм», «Фагодент») и антисептических средств - «Хлоргексидин» и «Мирамистин»..

Материалы и методы. Для изучения эффективности представленных антимикробных средств применяли штаммы культур Staphylococcus aureus и Streptococcus pyogenes как одних из самых часто встречающихся представителей патогенных микроорганизмов.

Изучение жизнеспособности клеток и цитотоксичности антимикробных средств проводили на клеточной линии КВ - эпидермоидной карциноме ротовой полости человека. Для этого применяли микротетразолиевый тест, который широко используется в оценке воздействия на клетки токсикантов, фармакологических препаратов, неблагоприятных факторов окружающей среды, позволяя оценить токсичность исследуемых препаратов in vitro.

Результаты исследований показали, что эффективностью против патогенных микроорганизмов Staphylococcus aureus и Streptococcus pyogenes даже в 10-кратном разведении обладают раствор «Хлоргексидина» 0,05\% и гели с бактериофагами. Антисептик «Мирамистин» эффективен только в исходной концентрации.

Изучение цитотоксичности средств показало, что обработка клеток эпидермоидной карциномы «Хлоргексидином» и «Мирамистином» приводит к запуску необратимых реакций, в то время как обработка композицией гелей на основе бактериофагов не влияет на дальнейшую жизнеспособность клеток.

Выводы. Результаты эксперимента подтвердили значительную токсичность таких средств, как "Хлоргексидин» и «Хлоргексидин» в предлагаемых в аптечной сети концентрациях. Несмотря на высокую эффективность этих средств в отношении изучаемых патогенов, их длительное применение в комплексном лечении воспалительных заболеваний кожи и слизистых оболочек может вызывать замедление процессов репарации.

Гелевые средства с бактериофагами «Фагодент», «Отофаг», «Фагогин» и «Фагодерм» высокоэффективны и не обладают токсическим действием на клетки. В связи с этим они могут являться эффективной и безопасной альтернативой популярным антисептическим средствам. 


\title{
THE STUDY THE EFFICACY AND SAFETY OF ANTIMICROBIAL AGENTS
}

\author{
Bagaeva V.V. ${ }^{1}$, Popova V.M. ${ }^{2}$, Pashkova G.S. ${ }^{3}$, Isadzhanyan K.E. ${ }^{4}$, \\ Nikitin V.V. ${ }^{5}$, Zhilenkov E.L. ${ }^{2}$ \\ Pokrovskiy stem cell bank (St. Petersburg, Russian Federation) \\ 199106, St. Petersburg, Russian Federation, Bolshoy Pr. V.0., 85 \\ ${ }^{2} \mathrm{RPC}$ «Micromir» (Lyubuchany, Russian Federation) \\ 142380, Moscow Region, Chekhovskiy r-n, pos. Lyubuchany, Engineering Institute of Immunology \\ ${ }^{3}$ A.I. Evdokimov KDK GBEO HPE MSMSU MH RF (Moscow, Russian Federation) \\ 127006, Moscow, ul. Dolgorukovskaya, 4 \\ ${ }^{4}$ SRIS and MFS (Moscow, Russian Federation) \\ 119021. Moscow, ul. Timura Frunze, 16 \\ ${ }^{5}$ «Klinika Bosco» (Moscow, Russian Federation) \\ 13107031, Moscow, ul. Neglinnaya, 13
}

\section{Abstract:}

Effective treatment of patients with infectious and inflammatory diseases of the skin and mucous membranes often involves the use of antimicrobial agents.

The purpose of the study was an in vitro estimation of cytotoxicity and the efficiency of national resources for local use: gel with bacteriophages («Otofag», «Fagogin», «Fagoderm», "Fagodent») and antiseptic — «Chlorhexidine» and «Miramistin».

Materials and Methods. To study the effectiveness of antimicrobial agents they used to provide crop strains of Staphylococcus aureus and Streptococcus pyogenes as one of the most common representatives of pathogens. The study of cell viability and cytotoxicity antimicrobials performed on cell lines KB - epidermoid carcinoma of the oral cavity of a human. For this purpose we use mikrotetrazoly test, which is widely used in the assessment of the effects on the cells of toxins, pharmaceuticals, adverse environmental factors, allowing to evaluate the toxicity of investigational drugs in vitro.

The results showed that the efficacy against pathogens

Staphylococcus aureus and Streptococcus pyogenes, has even a 10 -fold dilution of "Chlorhexidine» $0.05 \%$ and gels with bacteriophages. Antiseptic "Miramistin» is effective only on the initial concentration.

The study of cytotoxicity showed that the processing of epidermoid carcinoma cells with "Chlorhexidine» and "Miramistin" invokes the irreversible reactions, while the composition processing of gels based on bacteriophages not further affect cell viability.

Conclusions The results of the experiment confirmed the significant toxicity of tools such as "Chlorhexidine» and "Miramistin" in proposed concentrations in the pharmacy network. Despite the high efficiency of these vehicles with regard to the studied pathogens, their long-term use in treatment of inflammatory diseases of the skin and mucous membranes can cause a slowing of repair processes. Gel means with bacteriophages «Fagodent» "Otofag» "Fagogin" and "Fagoderm" are highly effective and have no toxic effects on the cells. In this regard, they can be an effective and safe alternative to the popular antiseptic.

\section{Актуальность проблемы}

В настоящее время профилактика и лечение инфекционно-воспалительных заболеваний являются одной из актуальных проблем в медицине. Бактериальная инфекция встречается во всех областях медицины, особенно часто в отоларингологии, гинекологии, хирургии, дерматологии и стоматологии [1-5]. Бактерии рода стрептококков и стафилококков являются наиболее частой причиной воспалительных заболеваний различных органов и систем организма человека. Эти микроорганизмы вызывают широкий спектр заболеваний от локальных форм, таких как пародонтит, вагинит, отит, фарингит, импетиго, до острых инфекционных заболеваний, таких как ангина, скарлатина, стрептококковый сепсис, стрептококковый шоковый синдром и т. д. [1-6]. Заболевания, вызванные стрептококками и стафилококками, широко распространены во всем мире. Исследования, проводимые в различных странах, указывают на рост заболеваемости населения и появление тяжелых форм заболевания, обусловленных изменчивостью возбудителей $[7,8]$.

Ведущими возбудителями воспалительных заболеваний являются Staphylococcus aureus и Streptococcus pyogenes, оказывающие на организм разностороннее действие в связи с наличием множества факторов патогенности. Среди последних, наиболее значимы экзотоксины, влияющие на органы на рецепторном уровне, изменяя их функцию и обуславливая особенности клинического течения заболевания [9-12].

Несмотря на многообразие различных методов лечения и профилактики бактериальной инфекции, у врачей всех специальностей вопрос эффективности применения антисептических и антибактериальных средств и препаратов остается нерешенным. В комплексном лечении инфекционно-воспалительных заболеваний кожи и слизистых оболочек одно из ведущих мест принадлежит местной антимикробной терапии [13-17]. Идеальный антимикробный препарат должен поражать патогенные микроорганизмы, в то же время, оказывая минимальное действие на представителей нормофлоры и на клетки человеческого организма. Одними из самых широко применяемых препаратов для местного воздействия на патогенные микроорганизмы являются антисептики [13-17]. 
Современные антисептические препараты обладают широким антибактериальным спектром и, по данным некоторых исследователей, не индуцируют появления резистентности микробов. Доминирующими факторами, определяющими широкое клиническое использование антисептиков, является положительный клинический опыт, доказанная эффективность in vitro в отношении простейших, бактерий, грибов и вирусов, составляющих видовое и количественное разнообразие микроорганизмов, вегетирующих в полости рта. Перечень антисептиков, применяемых в гинекологии, отоларингологии, дерматологии, стоматологии, достаточно широк и постоянно пополняется новыми препаратами, совершенствуются также и формы их выпуска [13-17].

Важнейшим критерием безопасности антимикробных средств является низкая токсичность в отношении клеток человеческого организма. Некоторые антимикробные препараты обладают непрямым токсическим действием и оказывают тератогенный эффект во время беременности [17].

Примером популярных антисептических средств могут служить широко используемые в настоящее время «Хлоргексидин» и «Мирамистин». Однако, наряду с достаточной эффективностью, данные препараты имеют ряд существенных недостатков. Имеются сведения о высокой цитотоксичности антисептических средств $[18,19]$.

В связи с этим необходим поиск альтернативных противомикробных препаратов с доказанной эффективностью и отсутствием возможных токсических эффектов на клеточном уровне. Современная медицинская наука уделяет все большее внимание поиску средств, действие которых может селективно подавлять размножение патогенов, свойственных конкретному заболеванию. Это связано с появлением все большего количества устойчивых форм бактерий и наличием побочных действий различных противомикробных средств. В связи с этим появился интерес к средствам на основе вирулентных бактериофагов, так как их действие направлено на этиологически значимые патогены [20-23].

Одним из естественных природных агентов, способных избирательно воздействовать на микроорганизмы, являются бактериофаги (вирусы бактерий). В Российской

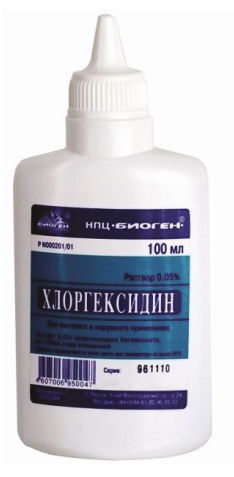

Рисунок 1.

0,05\% раствор хлоргексидина

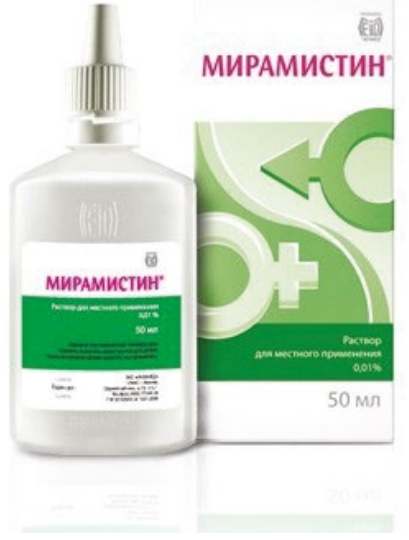

Рисунок 2.

0,01\% раствор мирамистина
Федерации на основе созданной учеными ООО НПЦ «МикроМир» коллекции бактериофагов, зарегистрированной в международной организации WFCC (инв. № 986), разработаны лечебно-профилактические средства с бактериофагами, действие которых направлено на патогены кожи, слизистой оболочки полости рта, желудочно-кишечного тракта, ЛОР-органы, мочеполовой системы.

Для борьбы с патогенами российскими микробиологами-вирусологами Поповой В.М. и ЖиленковымЕ.Л. на базе НПЦ «МикроМир» созданы профилактические средства для гинекологии «Фагогин», для дерматологии и хирургии (для обработки послеоперационных ран) «Фагодерм», для полости рта «Фагодент», для отоларингологии «Отофаг» на основе вирулентных бактериофагов, активных в отношении этиологически значимых патогенных микроорганизмов.

Целью исследований явилась оценка эффективности широко применяемых в медицине антисептических препаратов - «Хлоргексидина», «Мирамистина» и средств на основе бактериофагов, а также изучение цитотоксичности этих средств.

\section{Материалы и методы}

Для определения литической активности:

- 0,05\% раствора хлоргексидина («Хлоргексидин» (Рис. 1)),

- 0,01\% раствора мирамистина («Мирамистин» (Рис. 2)),

- геля «Фагодент» (с бактериофагами Aggregatibacter actinomycetemcomitans, Actinomyces israelii, Actinomyces spp., Bacteroides gracilis, Bacteroides forsythus, Campylobacter spp., Enterococcus faecalis, Fusobacterium spp., Porphyromonas gingivalis, Prevotella intermedia, Proteus vulgaris spp., Pseudomonas aeruginosa spp., Staphylococcus aureus spp., Streptococcus mitis, Streptococcus mutans, Streptococcus pyogenes spp., Streptococcus salivarius, Treponema denticola, Wolinella spp.)

- геля «Отофаг» (с бактериофагами к Bacteroides spp., Escherichia coli spp., Haemophilus influenzae spp., Klebsiella spp., Moraxella catarrhalis, Morganella morganii, Neisseria spp., Proteus vulgaris spp., Providencia rettgeri
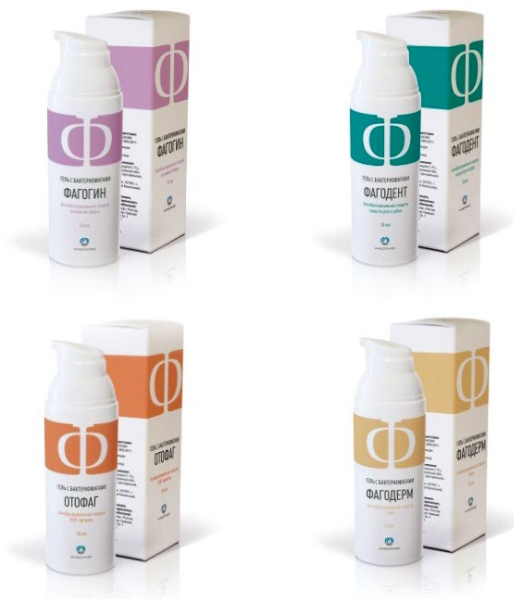

Рисунок 3.

Гели на основе бактериофагов (ООО НПЦ «МикроМир»). 


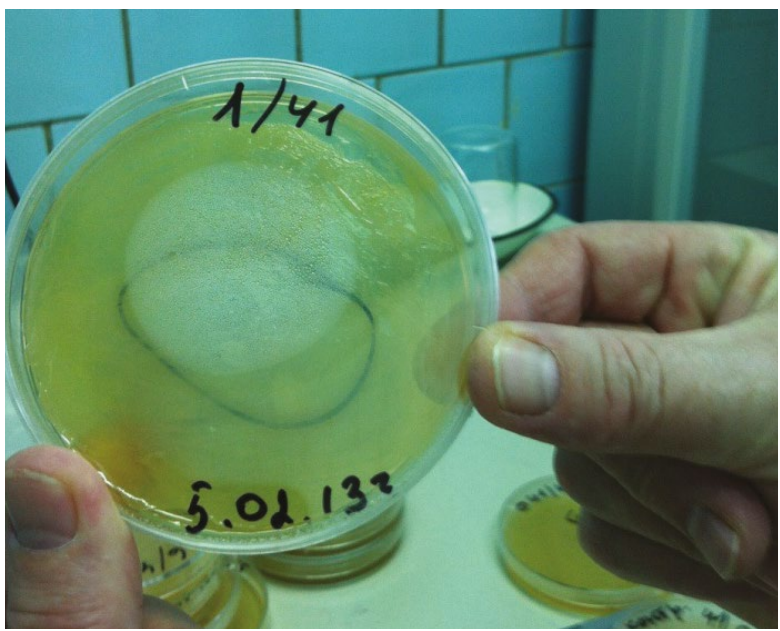

Рисунок 4. Эффективность «Хлоргексидина» в 10-кратном разведении в отношении штаммов Staphylococcus aureus.

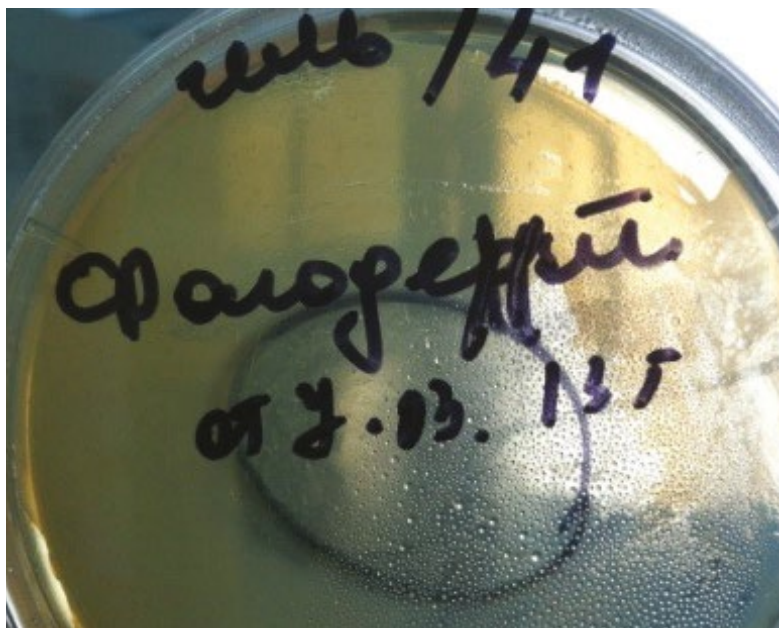

Рисунок 6. Эффективность бактериофагов средства «Фагодент» в 10-кратном разведении против штаммов Staphylococcus aureus.

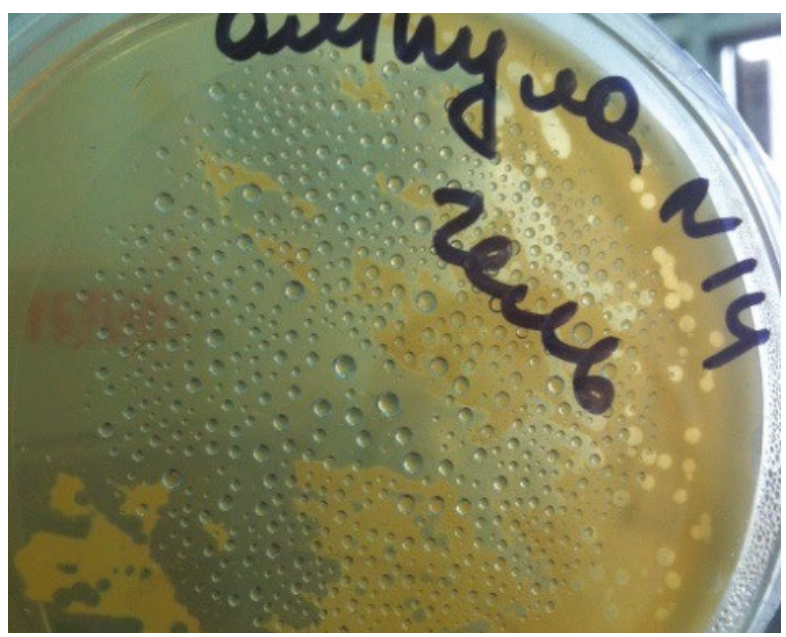

Рисунок 8. Эффективность бактериофагов средства «Отофаг» в 10-кратном разведении в отношении штаммов Staphylococcus aureus.

Исследования и практика в медицине. 2015, т. 2, № 3, с. 35-42

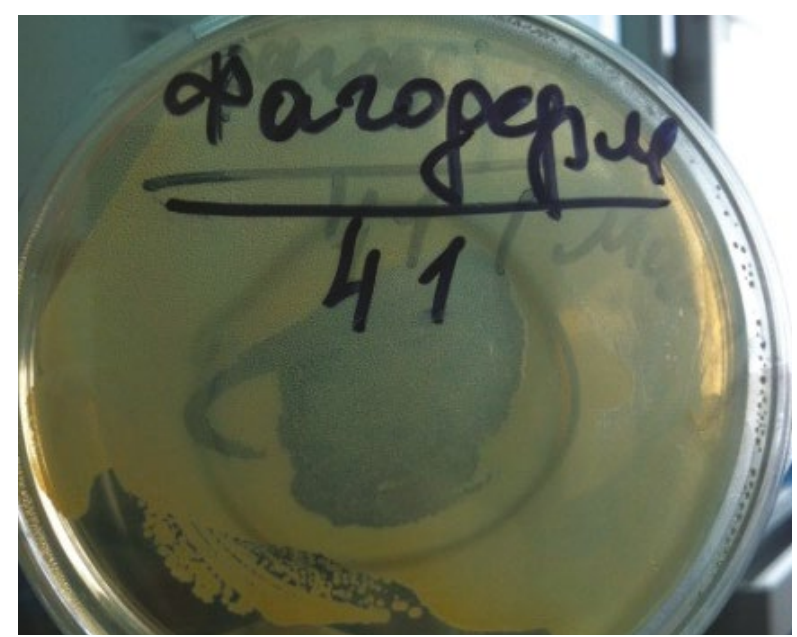

Рисунок 5. Эффективность бактериофагов средства «Фагодерм» в 10-кратном разведении против штаммов Staphylococcus aureus.

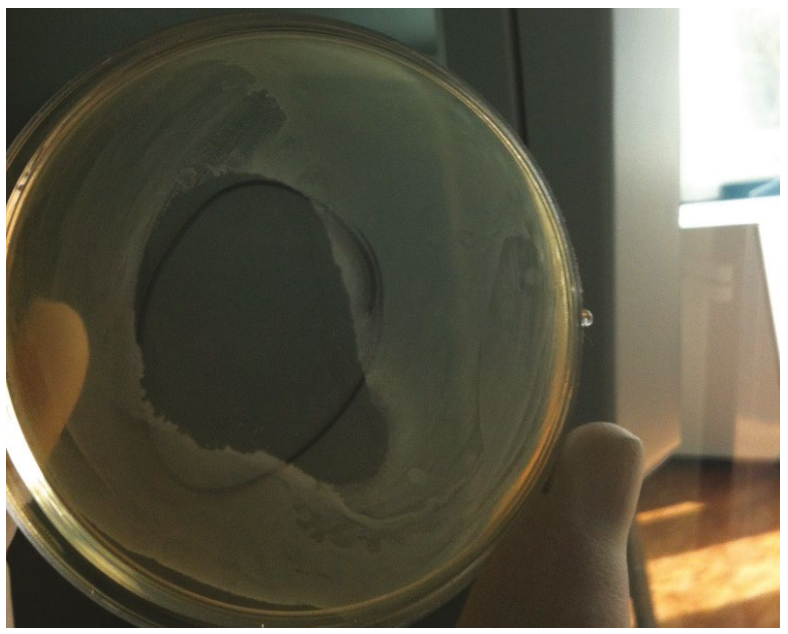

Рисунок 7. Эффективность бактериофагов средства «Фагогин» в 10-кратном разведении против штаммов Staphylococcus aureus.

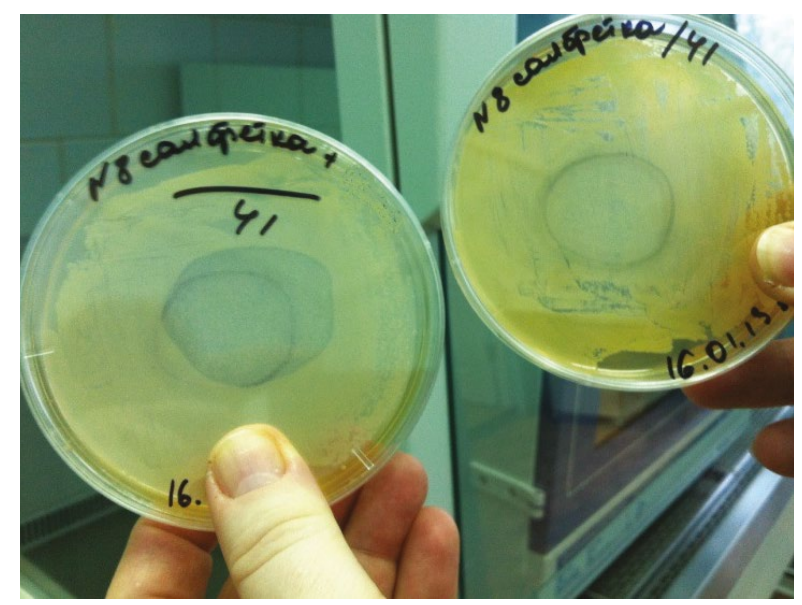

Рисунок 9. Слева- эффективность «Мирамистина» (в исходной концентрации), справа- отсутствие эффективности «Мирамистина» (2-кратное разведение) против штаммов Staphylococcus aureus. 
spp., Pseudomonas aeruginosa spp., Staphylococcus aureus spp., Streptococcus pyogenes spp.)

- геля «Фагогин» (с бактериофагами к Actinomyces spp., Bacteroides spp., Campylobacter spp., Enterobacter spp., Escherichia coli spp., Gardnerella vaginalis, Haemophilus spp., Hafnia alvei, Klebsiella spp., Neisseria gonorrhoeae, Proteus spp., Pseudomonas aeruginosa spp., Staphylococcus aureus spp., Streptococcus spp.)

- геля «Фагодерм» (с бактериофагами к Acinetobacter baumannii spp., Bacteroides fragilis, Bacteroides spp., Citrobacter freundii, Corynebacterium spp., Enterobacter spp., Escherichia coli spp., Klebsiella spp., Propionibacterium acnes, Providencia rettgeri spp., Proteus mirabilis spp., Proteus vulgaris spp., Pseudomonas aeruginosa spp., Staphylococcus aureus spp., Staphylococcus epidermidis spp., Streptococcus pyogenes spp.) (Рис. 3)

применяли штаммы культур Staphylococcus aureus и Streptococcus pyogenes как одних из самых часто встречающихся представителей патогенных микроорганизмов. Данные бактериальные штаммы выявляются как в пародонтальных карманах, так и на элементах поражения слизистой оболочки полости рта, носа, миндалинах, влагалища и коже при различных воспалительных заболеваниях.

Сначала проводили рассев указанных культур в чашках Петри с питательной средой Brain Heart Infusion с добавлением $10 \%$ стерильной дефибринированной крови. В центр чашки с культурой наносили каплю исследуемого антисептика. Посевы инкубировали в аэробных и анаэробных условиях. Наличие зоны лизиса в месте нанесения капли с препаратом расценивали как положительный результат. Наличие сплошного бактериального роста расценивали как отрицательный результат. В качестве контроля на бактериальный газон наносили 1 каплю физиологического раствора, в месте нанесения которого формировался сплошной бактериальный газон.

Для изучения жизнеспособности клеток и цитотоксичности антимикробных средств проводили исследование на клеточной линии КВ - эпидермоидной карциноме ротовой полости человека. Клетки вносили в лунки 96-луночного микропланшета (“Costar”) в количестве 30 тыс. клеток на одну лунку в 100 мкл культуральной среды. Затем в лунки добавляли тестируемые вещества (композицию гелей на основе бактериофагов, хлоргексидин, мирамистин) в двух, десяти и пятидесятикратных разведениях в ростовой среде (ДМЕМ +10\% FBS). Инкубацию проводили в условиях $\mathrm{CO}_{2}$-инкубатора в атмосфере $5 \% \mathrm{CO}_{2}, 80 \%$ влажности и при температуре $37^{\circ} \mathrm{C}$ в течение 20 минут и 1 часа. По окончании инкубации цитотоксичность измеряли с помощью МТТ теста.

Микротетразолиевый тест широко используется в оценке воздействия на клетки токсикантов, фармакологических препаратов, неблагоприятных факторов окружающей среды, позволяя оценить токсичность исследуемых препаратов in vitro.

МТT тест - это метод определения жизнеспособности клеточных культур. Его действие основано на способности живых клеток превращать растворимый желтый бромид 3- (4,5-диметилтиазол-2-ил)-2,5-тетразолия (МТT) в нерастворимые пурпурно-синие внутриклеточные кри- сталлы МТТ-формазана (МТT-ф). Нежизнеспособные клетки такой способностью не обладают. Интенсивность превращения МTT в МТT-ф отражает общий уровень дегидрогеназной активности исследуемых клеток и модулируется активностью сопряженных ферментных систем, например, дыхательной цепи переноса электронов и т. д.

Использовали рабочий раствор МТТ в концентрации $5 \mathrm{mr} / \mathrm{мл} \mathrm{на} \mathrm{основе} \mathrm{солевого} \mathrm{раствора} \mathrm{Хенкса.} \mathrm{После} \mathrm{окон-}$ чания совместной инкубации клеток и исследуемых веществ во всех лунках планшета была произведена смена среды на ростовую среду, содержащую по 10 мкл рабочего раствора МТТ. После 3 часовой инкубации в $\mathrm{CO}_{2}$-инкубаторе $\left(37^{\circ} \mathrm{C}, 5 \% \mathrm{CO}_{2}\right)$ в каждую лунку добавляли по 100 мкл SDS-HCl. Через 4 часа инкубации при стандартных условиях, после полного растворения кристаллов формазана измерялась оптическая плотность содержимого лунок на мультилуночном спектрофотометре ("MultiScan MCC 340", Labsystems) при длине волны 540 нм.

Жизнеспособность выражена в процентах и вычислена по формуле:

ЖСП (\%) $=($ ОПэ-ОПср)/ОПкк*100

Где: ОПэ- значение оптической плотности в опытных сериях;

ОПср - значение оптической плотности в лунках со средой;

ОПкк - значение оптической плотности в лунках с контрольными клетками.

Цитотоксичность выражена цитотоксическим индексом (ЦИ) в процентах.

Расчет ЦИ проводился по стандартной формуле:

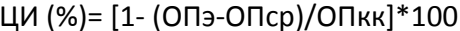

Где: ОПэ- значение оптической плотности в опытных сериях;

ОПср - значение оптической плотности в лунках со средой;

ОПкк - значение оптической плотности в лунках с контрольными клетками.

\section{Результаты исследования}

Результаты исследования показали, что эффективностью против патогенных микроорганизмов (Staphylococcus aureus, Streptococcus pyogenes) даже в 10-кратном разведении обладают “Хлоргексидин» 0,05\% и гели на основе бактериофагов «Фагодент», «Отофаг», «Фагогин», «Фагодерм» (Рис. 4,6,7,8,9). Антисептик «Мирамистин» эффективен только в исходной концентрации- 0,01\% (Рис. 9).

Оценка индекса цитотоксичности (Диаграмма 1) антисептических средств и жизнеспособности клеток эпидермоидной карциномы (Диаграмма 2) при взаимодействии со средствами показала, что «Хлоргексидин» и «Мирамистин» при 2-х кратном разведении являются высокотоксичными препаратами. Так, при 20 минутном воздействии жизнеспособными остаются только 9\% и 18\%, а при часовом- $2 \%$ и $1 \%$ соответственно. Значительно ниже уровень цитотоксичности выражен у «Хлоргексидина» и «Мирамистина» при 10-ти кратном разведении: жизнеспособность обработанных клеток составляет 98\% и 87\% после 20 минут и 76\% и $87 \%$ после часа соответственно. «Хлоргексидин» в 50 кратном разведении практически не повреждает клетки, оставляя жизнеспособными 97\% как через 


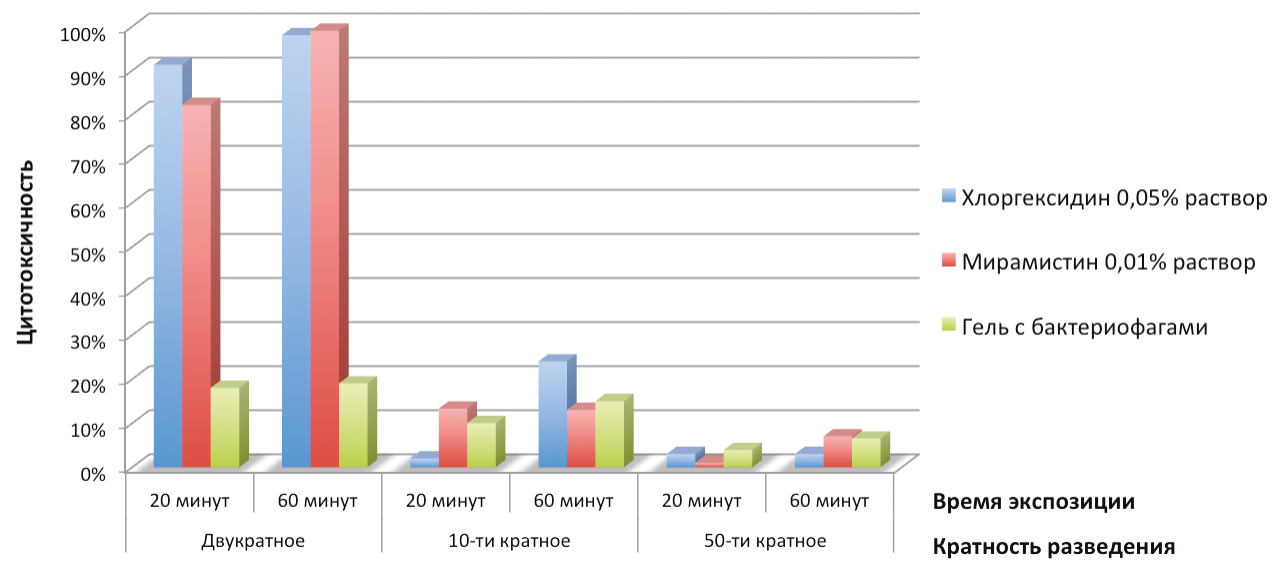

Диаграмма 1. Цитотоксичность антисептических препаратов в различных концентрациях, оценка после 20-минутного и часового воздействия.

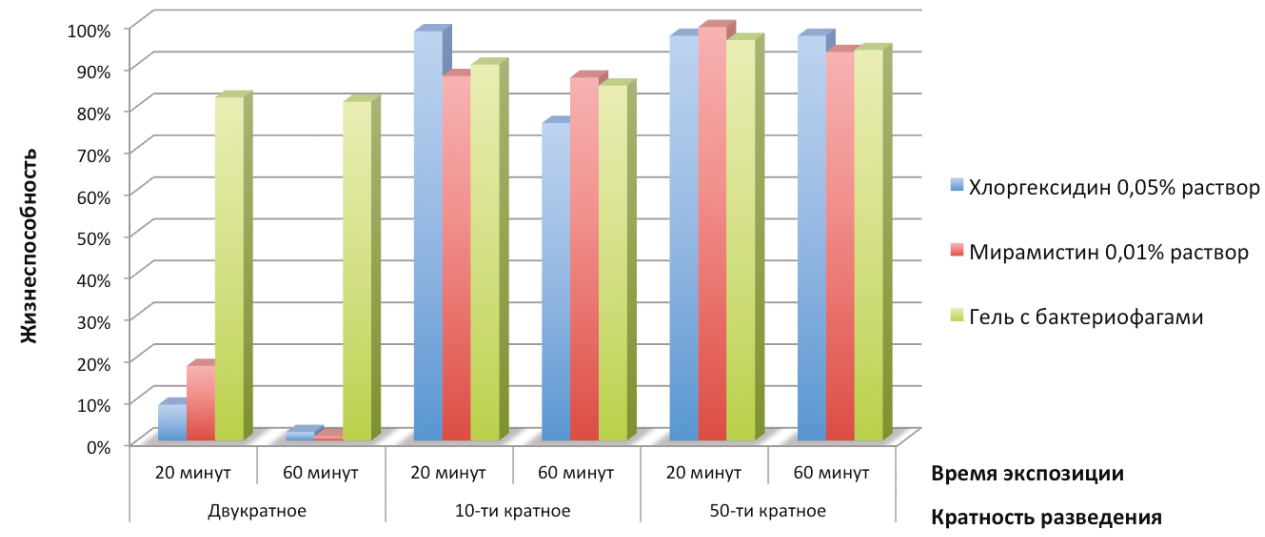

Диаграмма 2. Жизнеспособность клеток эпидермоидной карциномы после 20-минутного и часового воздействия антисептических средств.

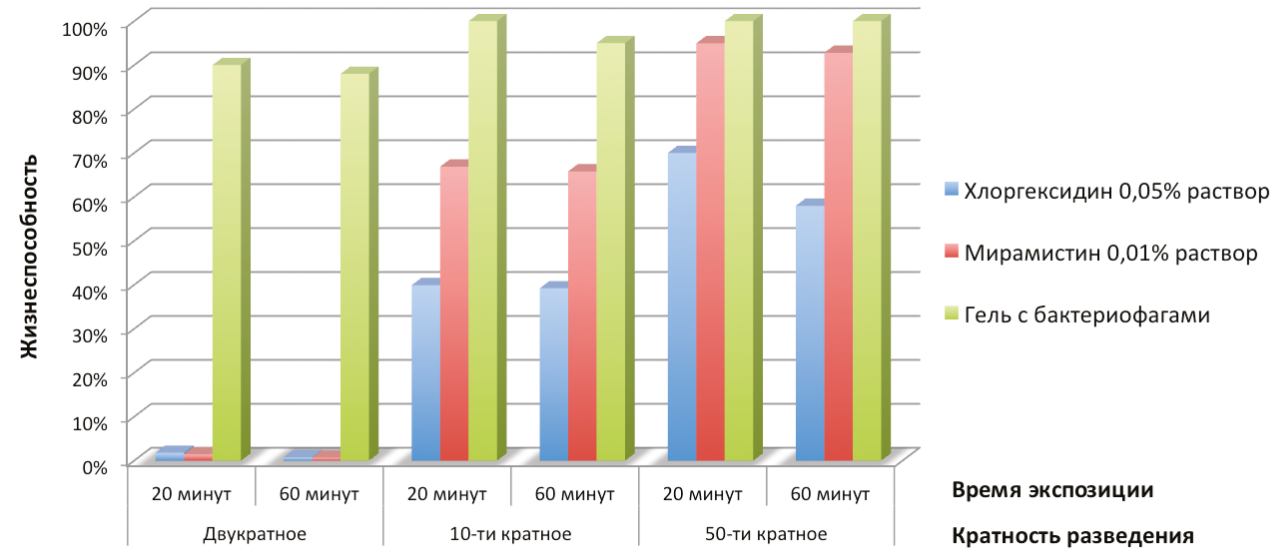

Диаграмма 3. Оценка жизнеспособности клеток, подвергшихся 20-минутному и часовому воздействию антисептических препаратов. Проведена через сутки после воздействия и удаления антисептика с поверхности клеток. 
20 минут, так и через час. Схожие значения и у обработанных «Мирамистином» клеток 99\% и 93\% после 20 минут и часа соответственно.

Гели на основе бактериофагов обладают слабовыраженной токсичностью. Уровень жизнеспособности клеток после воздействия композиции гелей при двукратном разведении сравним с клетками, подвергшимися воздействию растворов "Хлоргексидина» и «Мирамистина» в 50-кратном разведении. Инкубация с $10 \%$ раствором через 20 минут и 1 час приводит к сохранению 90\% и 85\% жизнеспособных клеток. Средства на основе бактериофагов в двукратном разведении сохраняют гелевую форму, что несколько снижает жизнеспособность клеток до $82 \%$ через 20 минут и 81\% через час. Возможно, наблюдаемый эффект обусловлен гелевой формой препарата, препятствующей поступлению кислорода к клеткам. Тем не менее, даже при 2-кратном разведении уровень цитотоксичности препарата «Фагодент» сравним по своим значениям с необработанными клетками.

Следует отметить, что влияние «Хлоргексидина» и «Мирамистина» является необратимым. Для изучения возможного восстановления жизнеспособности после двадцатиминутного и часового воздействия лекарственных средств среда была замещена на ростовую (ДМЕМ $+10 \% \mathrm{FBS}$ ) с дальнейшей инкубацией в течение 24 часов в $\mathrm{CO}_{2}$ инкубаторе в стандартных условиях. На следующие сутки была оценена жизнеспособность клеток. Результаты эксперимента отражены на Диаграмме 3.

В результате проведенной работы было установлено, что в высокой концентрации только воздействие гелей на основе бактериофагов не влияло на дальнейшую жизнеспособность клеток. Остальные препараты в 2-крат-

\section{Список литературы:}

1. Лопатин А. С., Гамов В. П. Острый и хронический риносинусит: этиология, патогенез, клиника, диагностика и принципы лечения. Учебное пособие. М.: МИА, 2014

2. Под ред. Макарова О. В., Алешкина В. А., Савченко Т. Н. Инфекции в акушерстве и гинекологии. М.: МЕДпресс-информ, 2009.

3. Шиханова Е.Н. Микробиоценоз акне-элементов у пациентов с угревой болезнью и его изменение под влиянием липосомальных форм антибиотиков: Дис. ... канд. мед. наук: 03.00.07/Ставр. гос. мед. акад. Ставрополь. 2009.

4. Хэбиф Т.П.; Пер. с англ. В.П. Адаскевич. Клиническая дерматология. Акнеподобные и папулосквамозные дерматозы. М.: МЕДпресс-информ, 2014

5. Грудянов А.И. Заболевания пародонта. М.: Медицинское информационное агентство, 2009.

6. Лабинская А.С., Костюкова Н. Н. и др. Под ред. А. С. Лабинской. Руководство по медицинской микробиологии. Книга 3. Том 2. М.: Бином, 2014.

7. Грабов И.И. Естественная индуцированная изменчивость микроорганизмов. Журнал микробиологии, эпизоотологии и иммунологии. 1988; 33: 18-23.

8. Мельникова В.М., Беленькая Г.М. Изменчивость некоторых биологических свойств стафилококков в зависимости от стадии и характера раневого процесса//Тезисы докладов XI Международной конференции по микробиологии. М., 1966. с. 427.

9. Romero, F.J., Bosch F.-Morell, Roma J. Lipid peroxidation products and antioxidants in human disease. Environmental Health Perspectives Supplements.1998; 106 (5): 1229-1234.

10. Peterson, P. K., Schmeling D., Gearylnhibition P. P., et al. Inhibition of alternative complement pathway opsonization by group $A$ streptococcal M protein. J Infect Dis. 1979; 139 (5): 75-85. ном разведении оказывали необратимое воздействие, приводящее к потере жизнеспособности клеток. В то же время после обработки "Хлоргексидином» в 10-кратном разведении жизнеспособность клеток восстанавливалась до 40\%, а после обработки «Мирамистином» в 10-кратном разведении до 67\%. При изучении влияния средств в 50-кратном разведении было выявлено, что незначительное снижение жизнеспособности клеток вызывает только «Хлоргексидин».

\section{Выводы}

Полученные в ходе экспериментов данные можно использовать как обоснование тактики антимикробного лечения инфекционно-воспалительных заболеваний, либо коррекции уже начатого. Результаты эксперимента подтвердили значительную токсичность таких средств, как «Хлоргексидин» и «Мирамистин» в предлагаемых в аптечной сети концентрациях. Несмотря на высокую эффективность этих средств в отношении изучаемых патогенов, их длительное применение в комплексном лечении воспалительных заболеваний кожи и слизистых оболочек может вызывать замедление процессов репарации.

Гелевые средства с бактериофагами «Фагодент», «Отофаг», «Фагогин» и «Фагодерм» высокоэффективны по отношению к использованным в эксперименте Staphylococcus aureus и Streptococcus pyogenes и не обладают токсическим действием на клетки. В связи с этим они могут являться эффективной и безопасной альтернативой популярным антисептическим средствам как при лечении заболеваний, вызванных указанными патогенами, так и в профилактических целях.

11. Schuetz, E. G., Furaya K. N., Schuetz J. D. Interindividual variati on in expression of P-glycoprotein in normal human liver and secondary hepatic neoplasms.J. Pharmacol. Exp. Ther. 1995; 275 (2): 1011-1018.

12. Greco, R. L., De Martino L., Donnarumma G., et al. Invasion of cultured human cells bi Streptococcus pyogenes. Res. Microbiol.1995; 146 (7): 5551-5560.

13. Анготоева И.Б., Пискунов Г.З. Лекарственные средства в практике оториноларинголога. М.: МИА, 2014.

14. Кулаков В.И., Серов В.Н., Гаспаров А.С. Гинекология. М.: МИA, 2005.

15. Пестрикова Т.Ю., Юрасова Е.А., Юрасов И. В. Медикаментозная терапия в практике акушера-гинеколога. М.: Литтерpa, 2011.

16. Под ред. Э. Финлея, М. Чаудхэри. Дерматология в клинической практике. М.: Практическая медицина, 2011.

17. Под ред. М. Ньюман, А. ван Винкельхофф; Пер. М. Лариной. Антимикробные препараты в стоматолгической практике. М.: Азбука, 2004.

18. Афиногенов Г.Е., Еропкина Е.М., Бондаренко В. М., Еропкин М.Ю. Исследование противомикробной активности и цитотоксичности антиинфекционных препаратов на модели культүры клеток человека. Журн. микробиол 1996; 5: 3-7.

19. Еропкина Е.М., Афиногенов Г.Е., Еропкин М.Ю. Сравнительное исследование антимикробного и цитотоксического действия антисептиков in vitro с применением модели культуры эмбриональных фибробластов человека. Токсикол. вестник. 1997; 2: 12-17.

20. Волков Е.А., Никитин В. В., Пашкова Г.С. и др. Использование средства на основе бактериофагов в комплексном лече- 
нии инфекционно-воспалительных заболеваний пародонта. Российский стоматологический журнал. 2013; 5: 11-13.

21. Никитин В.В., Пашкова Г.С., Исаджанян К.Е. и др. Поиск безопасных и эффективных методов коррекции баланса микрофлоры полости рта. Анализ опроса врачей-стоматологов. Пародонтология. 2014; 19 (2): 36-40.

22. Зурабов А. Ю., Каркищенко Н. Н., Попов Д. В. и др. Создание

\section{References:}

1. Lopatin A. S., Gamov V. P. Ostryi i khronicheskii rinosinusit: etiologiya, patogenez, klinika, diagnostika i printsipy lecheniya. Uchebnoe posobie. M.: MIA, 2014. (Russian)

2. Pod red. Makarova O. V., Aleshkina V. A., Savchenko T. N. Infektsii v akusherstve i ginekologii. M.: MEDpress-inform, 2009. (Russian)

3. Shikhanova E. N. Mikrobiotsenoz akne-elementov u patsientov s ugrevoi bolezn'yu i ego izmenenie pod vliyaniem liposomal'nykh form antibiotikov: Dis. ... kand. med. nauk: 03.00.07/Stavr. gos. med. akad. Stavropol'. 2009. (Russian)

4. Thomas P. Habif, Clinical dermatology: A color guide to diagnosis and therapy.5th edition. Elsevier Science. 2010.

5. 5. Grudyanov A. I. Zabolevaniya parodonta. M.: Meditsinskoe informatsionnoe agentstvo, 2009. (Russian)

6. Labinskaya A. S., Kostyukova N. N. i dr. Pod red. A. S. Labinskoi. Rukovodstvo po meditsinskoi mikrobiologii. Kniga 3. Tom 2. M.: Binom, 2014. (Russian)

7. Grabov I.I. Estestvennaya indutsirovannaya izmenchivost' mikroorganizmov. Zhurnal mikrobiologii, epizootologii i immunologii. 1988; ZZ: 18-23. (Russian)

8. Mel'nikova V.M., Belen'kaya G. M. Izmenchivost' nekotorykh biologicheskikh svoistv stafilokokkov $v$ zavisimosti ot stadii $i$ kharaktera ranevogo protsessa//Tezisy dokladov XI Mezhdunarodnoi konferentsii po mikrobiologii. M., 1966. s.427. (Russian)

9. Romero, F.J., Bosch F.-Morell, Roma J. Lipid peroxidation products and antioxidants in human disease. Environmental Health Perspectives Supplements.1998; 106 (5): 1229-1234.

10. Peterson, P. K., Schmeling D., GearyInhibition P. P., et al. Inhibition of alternative complement pathway opsonization by group $A$ streptococcal M protein. J Infect Dis. 1979; 139 (5): 75-85.

11. Schuetz, E. G., Furaya K. N., Schuetz J.D. Interindividual variation in expression of P-glycoprotein in normal human liver and secondary hepatic neoplasms. J. Pharmacol. Exp. Ther. 1995; 275 (2): 1011-1018

12. Greco, R. L., De Martino L., Donnarumma G., et al. Invasion of cultured human cells bi Streptococcus pyogenes. Res. Microbiol.1995; 146 (7): 5551-5560.

Информация об авторах:

1. Багаева Варвара Владимировна - биотехнолог лаборатории клеточных культур, Покровский банк стволовых клеток

2. Попова Валентина Михайловна - к.м.н., заместитель генерального директора НПЦ «МикроМир»

3. Пашкова Галина Сергеевна - к.М.Н., врач-стоматолог-хирург КДК ГБОУ ВПО МГМСУ им. А.И. Евдокимова МЗ РФ

4. Исаджанян Карина Ервандовна - аспирант ЦНИИС и ЧлХ

5. Никитин Владимир Викторович - врач-стоматолог-хирург, «Клиника Боско»

6. Жиленков Евгений Леонидович - к.б.н., заместитель генерального директора НПЦ «МикроМир» отечественной коллекции бактериофагов и принципы разработки лечебно-профилактических фаговых препаратов. Биомедицина. 2012; 1: 134-138.

23. Зурабов А.Ю., Жиленков Е.Л., Попов Д.В. и др. Фаговый препарат «Фагодерм» и перспективы его использованияв дерматологии и косметологии. Вестник Эстетической Медицины. 2012; 11 (3): 56-63.

13. Angotoeva I. B., Piskunov G.Z. Lekarstvennye sredstva v praktike otorinolaringologa. M.: MIA, 2014. (Russian)

14. Kulakov V.I., Serov V. N., Gasparov A. S. Ginekologiya. M.: MIA, 2005. (Russian)

15. Pestrikova T.Yu., Yurasova E.A., Yurasov I.V. Medikamentoznaya terapiya $v$ praktike akushera-ginekologa. M.: Litterra, 2011. (Russian)

16. Pod red. E. Finleya, M. Chaudkheri. Dermatologiya $v$ klinicheskoi praktike. M.: Prakticheskaya meditsina, 2011. (Russian)

17. Pod red. M. N'yuman, A. van Vinkel'khoff; Per. M. Larinoi. Antimikrobnye preparaty $v$ stomatolgicheskoi praktike. M.: Azbuka, 2004. (Russian)

18. Afinogenov G. E., Eropkina E. M., Bondarenko V. M., Eropkin M. Yu. Issledovanie protivomikrobnoi aktivnosti i tsitotoksichnosti antiinfektsionnykh preparatov na modeli kul'tury kletok cheloveka. Zhurn. mikrobiol. 1996; 5: 3-7. (Russian)

19. Eropkina E. M., Afinogenov G. E., Eropkin M.Yu. Sravnitel'noe issledovanie antimikrobnogo i tsitotoksicheskogo deistviya antiseptikov in vitro s primeneniem modeli kul'tury embrional'nykh fibroblastov cheloveka. Toksikol. vestnik. 1997; 2: 12-17. (Russian)

20. Volkov E.A., Nikitin V.V., Pashkova G.S. i dr. Ispol'zovanie sredstva na osnove bakteriofagov $v$ kompleksnom lechenii infektsionno-vospalitel'nykh zabolevanii parodonta. Rossiiskii stomatologicheskii zhurnal. 2013; 5: 11-13. (Russian)

21. Nikitin V. V., Pashkova G.S., Isadzhanyan K. E. i dr. Poisk bezopasnykh i effektivnykh metodov korrektsii balansa mikroflory polosti rta. Analiz oprosa vrachei-stomatologov. Parodontologiya. 2014; 19 (2): 36-40. (Russian)

22. Zurabov A.Yu., Karkishchenko N. N., Popov D. V. i dr. Sozdanie otechestvennoi kollektsii bakteriofagov i printsipy razrabotki lechebno-profilakticheskikh fagovykh preparatov. Biomeditsina. 2012; 1: 134-138. (Russian)

23. Zurabov A.Yu., Zhilenkov E. L., Popov D. V. i dr. Fagovyi preparat "Fagoderm» i perspektivy ego ispol'zovaniyav dermatologii i kosmetologii. Vestnik Esteticheskoi Meditsiny. 2012; 11 (3): 56-63. (Russian)

Information about authors:

1. Bagaeva Varvara Vladimirovna - biotechnologist of laboratory of cell cultures, Pokrovskiy stem cell bank

2. Popova Valentina Mikhailovna - PhD, vice director, RPC «Micromir»

3. Pashkova Galina Sergeevna - PhD, dentist surgeon, A.I. Evdokimov KDK GBEO HPE MSMSU MH RF

4. Isadzhanyan Karina Ervandovna - postgraduate, SRIS and MFS

5. Nikitin Vladimir Viktorovich - dentist surgeon, "Klinika Bosco»

6. Zhilenkov Evgeniy Leonidovich - PhD, vice director, RPC «Micromir»

Исследование проводилось в Покровском банке стволовых слеток, г. Санкт-Петербург, Большой пр. В.О., д. 85 и в НПЦ «МикроМир», Московская обл., Чеховский р-н, пос. Любучаны, Институт Инженерной Иммунологии.

The study was conducted in Pokrovsky stem cell Bank, 85, Bolshoy Pr. V.O., St. Petersburg and in RPC «Micromir», Engineering Institute of Immunology, pos. Lyubuchany, Chekhovskiy r-n, Moscow Region, 142380.

Оформление ссылки для цитирования статьи:

Багаева В.В., Попова В.М., Пашкова Г.С., Исаджанян К.Е., Никитин В.В., Жиленков Е.Л. Изучение эффективности и безопасности применения антимикробных средств. Исследования и практика в медицине. 2015; 2(3): 35-42. DOI: 10.17709/2409-2231-2015-2-3-35-42 Bagaeva V.V., Popova V.M., Pashkova G.S., Isadzhanyan K.E., Nikitin V.V., Zhilenkov E.L. The study the efficacy and safety of antimicrobial agents. Issled. prakt. Med. 2015; 2(3): 35-42. DOI: 10.17709/2409-2231-2015-2-3-35-42

Конфликт интересов. Все авторы сообщают об отсутствии конфликта интересов. Conflict of interest. All authors report no conflict of interest. 